УДК 811.111'272'276.6:32]:316.647.5

DOI https://doi.org/10.26661/2414-1135-2021-83-2

\title{
СОЦІОЛІНГВАЛЬНІ ТА ЛІНГВОПРАГМАТИЧНІ ПАРАМЕТРИ МОВЛЕННЄВОЇ ПОВЕДІНКИ БОРИСА ДЖОНСОНА
}

\author{
Аніканова Л. О. \\ студентка II курсу магістратури факультету іноземної філології \\ Запорізький національний університет \\ вул. Жуковського, 66, Запоріжжя, Украӥна \\ orcid.org/0000-0003-3627-0961 \\ anicanowa535@gmail.com \\ Снікеєва С. М. \\ доктор філологічних наук, професор, \\ завідувач кафедри англійської філології \\ Запорізький національний університет \\ вул. Жуковського, 66, Запоріжжя, Украӥна \\ orcid.org/0000-0001-5442-7876 \\ saniyazp25@gmail.com
}

\begin{abstract}
Ключові слова:
антропоцентризм, лінгвоперсонологія, соиіолінгвістика, мовна особистість, сочіальна група, комунікативні стратегії й тактики, толерантність.
\end{abstract}

Статтю присвячено висвітленню соціолінгвальних і лінгвопрагматичних характеристик мовлення чинного прем'єр-міністра Об'єднаного Королівства Великобританії та Північної Ірландії Бориса Джонсона за допомогою аналізу тих комунікативних стратегій і тактик, які політик використовує для висловленнясвогоставленнядо сучасних соціальнихтенденцій(толерантність і різноманіття), до представників різних соціогруп, що виділяються за расою, етнічноюабогендерноюналежністю, релігійнимивіруваннями, професійною або соціальною стратифікацією, способом життя тощо, а також до народних традицій і цінностей британського суспільства. Головною комунікативною інтенцією Б. Джонсона є створення й підтримання свого позитивного іміджу, для чого він за допомогою комунікативних прийомів i мовних засобів здійснює ідеологічний, інформаційний та емоційний вплив на британський соціум, дотримуючись національних традицій і водночас ураховуючи нові суспільно-політичні тенденції. Виявлено, що основними комунікативними тактиками, які відображають соціолінгвальні параметри мовної особистості британського політика, є висловлення подяки, засудження, контрастування, консолідація народу, репрезентація новинної цінності, експлікація соціальнополітичної позиції, інтимізація спілкування, інтегрування. Ці тактики актуалізуються за допомогою різних мовних засобів, таких як лексичні одиниці 3 амеліоративною конотацією, лексико-граматичні експресеми, стилістичні прийоми (тавтологія, алюзія, паралелізм, синонімічний повтор), слова та фрази, які належать до розмовного стилю. Установлено, що соціум, у свою чергу, впливає на вибір тем для виступів і комунікативних тактик, тобто на мовлення політика загалом. Соціолінгвальними параметрами мовної особистості політика є соціальні чинники формування його мовної особистості, наприклад, освіта та професійна діяльність, його ставлення до представників інших рас, етнічних груп і статей, різних релігій, професійних прошарків і стилів життя, а також його звертання до народних традицій i цінностей, тобто комплексна взаємодія мовної особистості із соціумом. Лінгвопрагматичний аспект допомагає систематизувати й узагальнити ті засоби, які об'єктивують зазначені соціолінгвальні характеристики в мовленні чинного прем'єр-міністра Великої Британії. 


\title{
SOCIOLINGUAL AND LINGUOPRAGMATIC PARAMETERS OF BORIS JOHNSON'S SPEECH BEHAVIOR
}

\author{
Anikanova L. 0. \\ Master's Degree Student of the Faculty of Foreign Philology \\ Zaporizhzhia National University \\ Zhukovskoho str., 66, Zaporizhzhia, Ukraine \\ orcid.org/0000-0003-3627-0961 \\ anicanowa535@gmail.com \\ Yenikeyeva S. M. \\ Doctor of Philological Sciences, Professor, \\ Professor at the Department of English Philology \\ Zaporizhzhia National University \\ Zhukovskoho str., 66, Zaporizhzhia, Ukraine \\ orcid.org/0000-0001-5442-7876 \\ saniyazp25@gmail.com
}

Key words: anthropocentrism, linguo-personology,

linguopragmatics, sociolinguistics, language personality, social group, communication strategies and tactics, tolerance.
The article is devoted to defining the sociolinguistic and linguo-pragmatic characteristics of the United Kingdom of Great Britain and Northern Ireland's current Prime Minister Boris Johnson's speech behavior by analyzing the communication strategies and tactics that the politician uses to express his attitude to the traditional national values and modern social trends of tolerance and political correctness concerning racial, ethnic, gender, religious, social and lifestyle diversity. The main communicative intention of B. Johnson is to create and maintain a positive image, for which he uses communicative techniques and language means to exert ideological, informational and emotional influence on British society, adhering to national traditions and at the same time taking into account new socio-political trends. The main communicative tactics that reflect the sociolinguistic parameters of B. Johnson's language personality are expression of gratitude, condemnation, contrast, consolidation of the people, representation of news value, explication of socio-political position, intimacy of communication, integration. These tactics are actualized by various language means, such as lexical units with ameliorative connotation, lexical and grammatical expressions, stylistic devices (tautology, allusion, parallelism, synonymous repetition), words and phrases that belong to the conversational style. It is noted that society, in turn, influences the choice of topics for speeches and communication tactics, i.e. the speech of a politician in general. The sociolingual parameters of the language personality of a politician are social factors forming his language personality, such as education and professional activities, his attitude to members of other races, ethnic groups and genders, different religions, professional backgrounds and lifestyles, and his appeal to folk traditions and values, i.e. the complex interaction of the linguistic personality with society. The linguopragmatic aspect helps to systematize and generalize the means that objectify these sociolinguistic characteristics in the speech of the current Prime Minister of the United Kingdom. 
Постановка проблеми в загальному вигляді. Головним об'єктом домінуючої в сучасному мовознавстві антропоцентричної парадигми знаходиться людина як носій, хранитель, користувач і творець певної мови. Носієм мови, або мовною особистістю, є людина як комплекс психофізичних властивостей індивіда, які дають змогу їй створювати і сприймати мовні повідомлення [1]. Варто зазначити, що витоками теорії мовної особистості слугували наукові студії В. фон Гумбольдта, В. Виноградова, Ю. Караулова, М. Бахтіна, О. Леонтьєва, Г. Богіна, А. Потебні, В. Вундта, К. Фосслера, Г. Штейнталя та ін. Широкий спектр підходів до вивчення мовної особистості репрезентовано низкою праць вітчизняних і зарубіжних авторів (Є. Боринштейн, С. Воркачов, С. Голик, І. Голубовська, О. Глазова, Л. Засєкіна, М. Іваницька, Ю. Караулов, В. Карасик, О. Куварова, В. Махінов, Е. Паніткова, А. Романченко, Л. Славова, T. Снітко, І. Синиця та ін.). Складність і багатогранність мовної особистості зумовлюють необхідність комплексного дослідження цього феномена $з$ позиції насамперед лінгвоперсонології, а також таких трансдисциплінарних підходів, як лінгвокультурологія, теорія комунікацій, когнітивна лінгвістика, психолінгвістика, лінгвопрагматика тощо.

Актуальність. Попри наявність численних студій, присвячених висвітленню окремих аспектів мовної особистості, назрілим є дослідження особливостей «коопераційної» взаємодії різних параметрів у процесі комунікативної діяльності мовця. Оскільки поняття «мовна особистість» має інтегральний характер і підтверджує тенденцію сучасної науки до синтезу, міждисциплінарної інтеграції знання, розширення та укрупнення об'єкта дослідження, що відрізняє іiі від попередніх тенденцій до атомізму, детального аналізу, надмірної диференціації [5, с. 80], важливим стає дослідження не лише окремих аспектів цього складного феномена, а й виявлення регулярних зв'язків між ними, кооперативних тенденцій, закономірностей взаємообумовленості тощо. Саме такий підхід, на нашу думку, є актуальним для сучасної лінгвоперсонології.

Метою дослідження $\epsilon$ висвітлення соціолінгвальних і лінгвопрагматичних параметрів мовленнєвої поведінки чинного прем'єр-міністра Сполученого Королівства Великобританії та Північної Ірландії Бориса Джонсона. У розвідці ми зосередимося на аналізі впливу соціолінгвальних чинників на мовленнєву поведінку зазначеної особистості, на його вибір стратегій і тактик комунікації для здійснення певних соціально зумовлених інтенцій і на селекцію мовних засобів для їх реалізації в ході адресної комунікації.
Об'єктом безпосереднього аналізу стала мовна особистість Б. Джонсона та його мовленнєва поведінка. Вибір цієї «елітарної мовної особистості» [7, с. 112] зумовлено належністю Б. Джонсона до елітарного типу національної мовленнєвої культури в просторі політичного дискурсу, його публічним статусом, непересічністю особистості цього політика, його оригінальним мисленням та індивідуальною манерою комунікації.

Предметом дослідження стали соціолінгвальні й лінгвопрагматичні аспекти мовлення Б. Джонсона як мовної особистості, висвітлення специфіки його мовленнєвої поведінки, яка зумовлена саме суспільно-культурними чинниками та стратегіями й тактиками політичної комунікації.

Виклад основного матеріалу. Як зазначають дослідники, «мова в соціолінгвістичній парадигмі є варіантом» $[11$, с. 358$]$, саме тому релевантним є дослідження індивідуальних варіантів використання мови, тобто мовлення індивіда. Традиційно соціолінгвістику визначають як «маргінальну галузь мовознавства, що вивчає вплив суспільних явищ і процесів на виникнення, розвиток, соціальну й функціональну диференціацію мов, а також зворотний вплив мови на соціум» $[8$, c. 316]. Із цього визначення можна зробити висновок, що недостатньо вивченим залишається соціолінгвістичний аспект мовлення індивіда.

Серед останніх публікацій на цю тему варто відзначити роботи М. Дубовицької та Н. Філатової, у яких вони теоретично обгрунтовують релевантність дослідження соціолінгвальних параметрів мовної особистості, відзначаючи, що соціальна сутність мови відображена в мовній свідомості, носієм якої $є$ мовна особистість [2, с. 26], саме тому соціолінгвістичний аспект $€$ одним із основних під час аналізу індивідуальних особливостей мовлення.

Мовна особистість, за визначенням дослідників, є «сукупністю (i результатом реалізації) здібностей до створення та сприйняття мовленнєвих творів, які відрізняються ступенем структурно-мовної складності, глибиною й точністю відображення дійсності, певною цільовою спрямованістю» [4, с. 238]. Тобто мовленнєві твори є основним об'єктом аналізу. На мовленнєві твори, тобто мовленнєві акти, впливають різні екстралінгвальні фактори, одним із яких є ситуація спілкування [12, с. 124], саме тому в статті ми розглянемо такий складник, як точність відображення дійсності, адже мовленнєва поведінка мовної особистості політичного лідера залежить від домінуючих тенденцій у суспільстві, тобто відображає навколишню дійсність.

Економічні, соціально-політичні, етичні, екологічні проблеми, які нині турбують усе людство загалом та англійськомовне суспільство зокрема, 
впливають на функціонування мови й спричинюють зміни в складі їі системи. До таких викликів сучасного світу належать боротьба 3 пандемією коронавірусу та його економічними наслідками, охорона навколишнього середовища, захист принципів расової та гендерної толерантності. Б. Джонсон як представник політичної еліти Великої Британії має захищати філософію толерантності й політичної коректності, що зумовлює обрання відповідних стратегій і тактик комунікації з широкою адресною аудиторією громадян країни та вживання адекватних і влучних мовних засобів для їх реалізації.

На думку Л. Засєкіна, мовна особистість є суб' єктом, мова якого найповніше відтворює культурну спадщину свого народу, що виявляється у вербальних та екстралінгвальних елементах комунікації, мовних стереотипах, правилах етикету [3, с. 83]. Б. Джонсон як представник політичної еліти загалом володіє тими пізнавальними, емоційними й мотиваційними якостями, які забезпечують його мовну компетенцію як суб'єкта політичного дискурсу й індивіда національно-культурного простору Британії. Попри свою екстравагантність та емоційність, Б. Джонсон загалом дотримується традиційних норм культури мовлення, регламенту й правил комунікації в політичному дискурсі. Проте, відповідаючи на сучасні соціально-політичні виклики, прем'єрміністр Британії змушений прилаштовуватися до нових ідеологічних настанов, що впливає на зміст і форму його текстових звернень і мовленнєву поведінку. Отже, зміна політичної філософії та оновлення ідеологічних настанов стали тими соціолінгвальними чинниками, що спричинили модифікацію комунікативної поведінки політика та приведення до відповідності лінгвопрагматичних параметрів його риторики.

Розглянемо «коопераційні» зв'язки між соціолінгвальними чинниками й лінгвопрагматичними параметрами мовлення Б. Джонсона детальніше. Характерною рисою мовної особистості політика вважають експліцитну та імпліцитну підтримку або засудження дискримінації стосовно певних соціальних груп [13, с. 324]. Соціальні групи можуть бути виокремлені за статтю, віком, етнічною й расовою, професійною належністю. У політичному дискурсі комунікативна взаємодія між соціальними групами та мовною особистістю політичного лідера $є$ ключовою.

Як уже зазначалося, у сучасному політичному дискурсі домінують концепти толерантності й політкоректності, різноманіття, адже «толерантність $€$ необхідною для функціонування сучасних, ліберальних форм демократії. [...] Різноманіття має багато форм: думка та мовлення; одяг і зовнішність; мова; релігія; цінності та стилі життя» [10].
Ці базові концепти представлені в опозиції до поняття упередженості, зокрема мовної упередженості, яка «спрямована проти певної соціальної групи в усному чи писемному дискурсі у висловлюваннях представників інших соціальних груп» $[13$, с. 325]. Б. Джонсон як представник соціогрупи політиків у мовленні має висловлювати єдність 3 представниками всіх груп суспільства. На прикладі висловлювань Бориса Джонсона можна проаналізувати експліцитне мовне вираження толерантності або упередженості стосовно певних прошарків суспільства.

Як зазначають дослідники, «соціальними групами, які страждають від упередженості в багатьох соціальних контекстах, $є$ представники іншої раси, робітничого класу, ЛГБТ, етнічних меншин, певних релігій, певних країн, а також жінки та люди з вадами» [13, с. 324]. Дослідники вважають, що «у процесі соціальної інтеракції поведінка комуніканта підпорядкована певним комунікативним цілям, досягненню яких сприяє реалізація комунікативних стратегій і тактик» [6], саме тому доцільним уважаємо аналіз стратегій і тактик, які використовує політик для впливу на соціум. У дослідженні ми також проаналізуємо мовні засоби вираження ставлення політика до представників іншої раси, етнічної групи або статі, різних релігій, професійних прошарків тощо.

У дослідженні ми зосередилися на аналізі текстів у твітері прем'єр-міністра Великої Британії, оскільки, на наш погляд, цей сучасний канал комунікації дає можливість регулярно відстежувати оперативну реакцію політика на різні події суспільного життя. У текстовій письмовій формі твітер репрезентує осмисленні факти й виваженні думки автора повідомлень стосовно подій і процесів суспільного життя, відбиває прагматичні інтенції мовця й дає змогу виявити типові для його мовлення засоби, за допомогою яких він досягає своїх комунікативних цілей.

Аналіз соціолінгвальних і лінгвопрагматичних параметрів мовної особистості Б. Джонсона ми здійснюватимемо шляхом визначення комунікативної мети, подальшого виокремлення й аналізу мовних (лексичних, граматичних, стилістичних) засобів і комунікативних (стратегій, тактик) прийомів реалізації авторських інтенцій. Такий підхід дає змогу нам відслідкувати й описати мовленнєву поведінку цього політика, виявити, до яких саме комунікативних прийомів удається політик задля досягнення певних прагматичних цілей i посилення впливу на адресну аудиторію, якими мовними засобами послуговується для реалізації своїх намірів.

Стратегією комунікації Б. Джонсона в політичному дискурсі є створення власного позитивного образу захисника національних традицій Великої 
Британії, прибічника єдності британців незалежно від їхньої етнічної належності, поборника толерантності й політкоректності, борця за рівні права і свободи представників різних соціогруп британського суспільства. Для реалізації цієї стратегії політик удається до використання широкого спектру комунікативних тактик, для актуалізації яких у текстах своїх повідомлень у твітері він уживає різноманітні лінгвальні засоби, якими досконало володіє завдяки своїй мовній компетенції, належній освіті, ерудиції та досвіду спілкування з електоратом протягом політичної кар'єри.

Як ми зазначили, головною метою комунікативної поведінки політика $є$ створення позитивного іміджу, що головним чином досягається за допомогою схвалення або засудження певних тенденцій у сучасному суспільстві. Однією з негативних тенденцій $є$ дискримінація за расовою належністю, гендерною ознакою, зовнішністю, способом життя тощо. Б. Джонсон у висловлюваннях наголошує на своєму негативному ставленні до будь-якого виду дискримінації: Great to sign a huge@England flag in support of the@FA Respect campaign. Discrimination has no place in football [9]. У цьому прикладі засобом актуалізації негативного ставлення є тактика засудження. Крім того, він застосовує тактику контрасту: Hi folks, I'm very proud to have signed this amazing Nationwide flag supporting England and supporting all the values that our country represents, particularly ensuring that we have respect for diversity across our country [9]. Лексичними одиницями, які вербалізують ідею поваги до різноманіття, є слова і словосполучення з позитивною конотацією (very proud, amazing, values, respect, diversity). Б. Джонсон також застосовує тактику консолідації народу за допомогою апелювання до спільних футбольних традицій і легендарних діячів цієї професійної соціогрупи: I'm proud of this. I've added my signature to the names of such legends as Gareth Southgate, Geoff Hurst, Peter Shilton. And anyway, come on England in the match today [9]! До речі, ту саму тактику консолідації в поєднанні з тактикою репрезентації новинної цінності політик використовує у зверненні до британців через свій твітер після завершення локдауну, наголошуючи на можливості повернутися до пабів, що є ще однією спільною національною традицією всіх прошарків суспільства: Great to be back at the pub again, and to see so many reunited with friends and family [9]. Цю тактику вербалізовано за допомогою лексичних одиниць з амеліоративною конотацією (great, reunited).

Іншої соціогрупою британського суспільства, проти якої часто мають упередження, є представниці жіночої статі. Прем'єр-міністр у висловлюваннях звертає увагу на «гендерний пробіл» у системі охорони здоров'я: I'm appealing for women of all ages to help us with our Women's Health Strategy. We know there's a gender gap in our health system, and we are committed to ending it [9]. Комунікативна тактика експлікації соціально-політичної позиції допомагає політику прямо висловлювати своє ставлення до цієї проблеми: One of the inequalities in the healthcare system at the moment is that women tend to have fewer years in good health than men on average. And maybe that's because too much of the healthcare system is designed by men, for men. And we don't understand enough about women's direct experience of how healthcare works for them [9], використовуючи лексичні одиниці 3 негативною конотацією (inequalities) і стилістичний прийом тавтології (by men, for men).

Окрім цього, Б. Джонсон підкреслює важливість доступності освіти для дівчат у всьому світі: Making sure girls get 12 years of quality education is one of the smartest investments we can make as we recover from COVID-19. During our (a) G7 Presidency I'll be urging the world to take action and prevent a lost pandemic generation [9]. Лексико-граматична експресема (прикметник найвищого ступеня порівняння) the smartest, експресивно забарвлене дієслово urge та алюзія на відоме літературне поняття «втрачене покоління» (lost generation) є мовними засобами актуалізації тактики експлікації соціально-політичної позиції в наведеному прикладі.

Наступною соціогрупою, яка потерпає від упередженого ставлення, є представники ЛГБТ. Б. Джонсон використовує тактику експлікації соціально-політичної позиції: I think that what we want for this country is for it to be a place where you can be who you want to be and love whomsoever you want to love. That's what we want for this country. And I have a very simple reason for thinking that's the right thing. And it was born of long experience, really, of running one of the greatest cities in the world. If you want to have the most dynamic, thriving, tech, scientific, academic, cultural, artistic sector in the world, if you want to attract the best and brightest from around the world, then you should be progressive on these issues. I want you to know that we, you know, we've got your back, here in this government. We're determined to stick up for equalities for LGBT people in any way that we can. And we, we will keep going. Thankyou all for coming and see you next year [9], вербалізуючи іiі за допомогою стилістичного прийому паралелізму (you can be who you want to be and love whomsoever you want to love), лексико-граматичних експресем (найвищого ступеня порівняння прикметників: the most dynamic, thriving, tech, scientific, academic, cultural, artistic; the best and brightest). Крім того, він використовує тактику інтимізації спілкування, уживаючи розмовні вставні слова та фрази (really, you know). 
У багатьох мультинаціональних країнах існують конфлікти між представниками різних етнічних груп і релігій. Завдяки соціальному статусу Б. Джонсон має змогу висловлювати підтримку представникам усіх народностей i вірувань, насамперед вітаючи їх із важливими святами. У наведеному прикладі він вітає християн із Великоднем, використовуючи тактику інтегрування: Happy Easter to everyone who is celebrating today. I know that for many people that means chocolate eggs and the Easter bunny and hot cross buns and all the rest of it and I will certainly be joining in [9]. Крім того, він використовує стилістичний прийом алюзіi (Jesus Christ is "the way, and the truth, and the life", Good Samaritans): But if there's one thing British Christians have shown us this year is that Jesus Christ is "the way, and the truth, and the life" not just today but every day [9], адаптуючи відомі релігійні вислови: Millions of Good Samaritans each of them showing what loving thy neighbour as thyself really looks like in 21st century Britain [9] i використовуючи застарілі форми слів (loving thy neighbour as thyself), що надає висловлюванням більшої урочистості.

Представників ісламу політик також вітає 3 початком священного місяця: Ramadan Mubarak to all those observing Islam's holiest month this year. I'm afraid that again this year it is necessary to follow the rules to stay safe but I hope this month of fast, prayer and charity brings much peace and reflection to all Muslims [9]. У наведеному прикладі використано тактику апеляції до етнічних цінностей і тактику афіліації, зокрема використано аутентичну фразу-привітання (Ramadan Mubarak), як і в наступному висловлюванні (Eid Mubarak, iftar): Eid Mubarak to everyone here in the UK and around the world who is celebrating today. I realise that, once again, the end of the holy month is not being marked with quite as much fanfare as would normally be the case, but as I found when I joined a virtual iftar with key workers and volunteers last month, Muslims right across the UK are extraordinary adept at finding new ways to conduct the kind of age-old rituals that help bring communities together at a time like this [9]. У привітанні використовується стилістичний прийом синонімічного повтору (extraordinary, amazing, wonderful): I spoke to those who have been vaccinating care home residents, delivering food to hospital staff, stitching masks, organising funerals, working in fire and rescue services, and it was truly touching. I know that the amazing men and women I spoke to are just a handful of the many, many Muslims across the UK who have given so much in the fight against cironavirus. An amazing, wonderful community working so hard not only for your own friends and families, but for each and every one of us here in the UK [9], а також тактика інтимізації спілкування, яка вербалізується за допомогою емоційно забарвленої лексики (truly touching), що виражає особисте ставлення політика.

Крім позитивних моментів, прем'єр-міністр звертає увагу й на випадки дискримінації та порушення прав людини, використовуючи тактики засудження й інтегрування: This morning I spoke with some of those who have been shining a light on the gross human rights violations being perpetrated against Uyghur Muslims. I stand firmly with them and the other British citizens sanctioned by China [9], які актуалізуються за допомогою експресивної (gross, firmly) та негативно забарвленої лексики (violations).

Іншим видом дискримінації соціогруп за етнічною належністю $є$ антисемітизм: There is no place for antisemitism in our society. Ahead of Shavuot, I stand with Britain's Jews who should not have to endure the type of shameful racism we have seen today [9], ставлення до якого політик висловлює за допомогою тактик засудження (no place, shameful racism) та інтегрування (I stand with Britain's Jews).

Ще одним важливим аспектом $\epsilon$ вшанування важливих дат в історії кожної етнічної групи, наприклад, День вижилих у Голокості: Pleased to support the first \#HolocaustSurvivorDay and to honour the extraordinary contribution of Holocaust survivors to the UK and the world [9]. Це є ще одним прикладом тактики інтегрування.

Тактика висловлення подяки застосовується часто під час пандемії для підкреслення внеску кожної етнічної групи в загальнонародну справу боротьби з вірусом: This morning I met with Jewish community leaders. I want to thank Britain's Jews for the huge contribution they have made in responding to the pandemic. I stand with them against the shameful antisemitism we've seen in the past few days. It has no place whatsoever in the UK [9]. Подяка висловлюється за допомогою експресивних лексичних одиниць (huge), а також тактики інтегрування (I stand with them).

Представників єврейської спільноти політик також вітає зі святами за допомогою тактики афіліації, використовуючи в привітанні слова та фрази 3 мови їдиш (Chag kasher v'sameach, Pesach, Matzah Ramble, Seder, Charoset): Chag kasher v'sameach to everyone celebrating \#Passover this week. Sadly, for the second year in a row, this most sociable of festivals is taking place at a time when families, friends and neighbours are unable to come together as they usually would. But our fantastic Jewish community is known for its strength and for its resilience. And I know you're not going to let coronavirus stop you marking Pesach. You ancestors have done often in the most difficult of circumstances for many thousands of years. From Monday, you'll be able to meet up outdoors with up to six people or two 
households for a small, but perfectly formed, Matzah Ramble. And many of you once again will see time honoured rituals given a 21st century makeover with the return of online Seder. Even second time around, it's not quite what everyone is used to. But the Charoset will be just as sweet, and the Matzah just as meaningful. And you get something generations of Jews have dreamed of for millennia - the ability to mute the table's inevitable kvetch. So things will be a bit different this year, but you can still celebrate this week. Just make sure you stay safe and keep following the rules. Have a great Passover [9].

Таку ж тактику афіліації застосовано й для звернення до народу Уельсу: Da iawn Cymru, da iawn! Huge congratulations to @Cymru on getting through to the next round of \#EURO2020 [9]. У наведеному прикладі Б. Джонсон використовує традиційну назву країни $(C y m r u)$ та привітання валлійською мовою (Da iawn Cymru, da iawn!), як і в наступному висловлюванні (Diolch, Dydd Gîwyl Dewi Hapus): I want to wish everybody in Wales and Welsh people around the world a very happy Saint David's Day. Diolch for everything you are doing and Dydd Gîyl Dewi Hapus! [9].

Національним святом для ірландців є День Святого Патріка і привітання із цим святом є ще одним способом реалізації тактики інтегрування: Hi folks, it's Boris Johnson wishing a very happy Saint Patrick's Day to everybody here in Northern Ireland and indeed throughout the world. And I'm sure that Irish people are going to be raising a glass, to Armagh's most famous resident, I think it was TA Daly who said that on the 17th of March, everybody feels a little bit Irish, so have a very happy Saint Patrick's Day [9]. Підкреслюючи свою обізнаність в етнокультурі ірландців, Б. Джонсон двічі вітає ix із дорогим для них святом (a very happy Saint Patrick's Day) і наголошує на причетність до них, цитуючи відомого представника цього народу (everybody feels a little bit Irish).

Висновки. У результаті проведеного аналізу емпіричного мовного матеріалу встановлено, яким чином сучасні соціально-політичні чинники впливають на мовленнєву поведінку Б. Джонсона, на обрання ним стратегій і тактик комунікації для реалізації певних соціально зумовлених та особистісно-іміджевих інтенцій. Соціолінгвальними параметрами мовної особистості політика ми вважаємо соціальні чинники формування його мовної особистості (освіту, елітарний статус і політичну діяльність), дотримання ним національних традицій і відстоювання цінностей його країни, а також відстоювання актуальної для сучасного світу ідеології толерантності, політичної коректності, терпимого ставлення до представників інших рас, етносів, статей, релігій, професійних прошарків, соціальних груп.
Тісно пов'язаний із соціолінгвальними чинниками лінгвопрагматичний аспект мовленнєвої поведінки Б. Джонсона виявляється у визначенні ним стратегій комунікації та в обранні релевантних тактик спілкування, для реалізації яких мовець користується мовними засобами, які, на його погляд, адекватно й вдало репрезентують його думку. Оскільки твітер містить друковані текстові повідомлення, їх автор має змогу виважено обирати комунікативні прийоми й користуватися широким арсеналом мовних засобів, водночас здійснюючи самоконтроль 3 метою запобігання помилкам у змісті й формі повідомлення.

Оскільки головною стратегією комунікативної діяльності Б. Джонсона в політичному дискурсі є підтримка власного позитивного іміджу захисника національних традицій Великої Британії, прибічника єдності британської нації, поборника толерантності й політкоректності, який відстоює права і свободи представників різних соціогруп британського суспільства, у письмових повідомленнях він використовує релевантні тактики й прийоми. Виявлено, що характерними комунікативними тактиками, до яких Б. Джонсон удається в повідомлення у твітері, є висловлення подяки, засудження, контрастування, консолідація народу, репрезентація новинної цінності, експлікація соціально-політичної позиції, інтимізація спілкування, інтегрування. До типових засобів мовної реалізації комунікативних тактик належить уживання лексичних одиниць 3 амеліоративною конотацією, лексико-граматичних експресем, певних стилістичних прийомів (тавтології, алюзії, паралелізму, синонімічного повтору), слів і фраз, які належать до розмовного стилю.

Перспективами подальших студій уважаємо дослідження лінгвокогнітивних i психолінгвістичних параметрів мовної особистості Бориса Джонсона.

\section{ЛІТЕРАТУРА}

1. Воркачев С.Г. Лингвокультурология, языковая личность, концепт: становление антропоцентрической парадигмы в языке знаний. Филологические науки. 2001. № 1. C. 64-72.

2. Дубовицкая М.А., Филатова Н.П. Социолингвистический аспект характеристики языковой личности. Язык и мир изучаемого языка : сборник науч. стат. Саратов : Саратовский социально-экономический институт (филиал) федерального государственного бюджетного образовательного учреждения высшего образования «Российский экономический университет им. Г.В. Плеханова», 2019. C. 26-31. 
3. Засєкіна Л.В. Мовна особистість в сучасному соціальному просторі. Соціальна психологія. Київ : Український центр політичного менеджменту, 2007. № 5 (25). С. 82-89.

4. Караулов Ю.Н. Русский язык и языковая личность. 7-е изд. Москва : Изд-во ЛКИ, 2010. $264 \mathrm{c}$.

5. Ольшанский И.Г. Язык и языковая личность в условиях современного социального контекста. РГСУ. Ученые записки. 2004. № 1. C. $79-80$.

6. Павлова Л.В., Тарасова Г.С. Комунікативні стратегії і тактики в англомовному політичному медіадискурсі. Вчені записки ТНУ ім. В.І. Вернадського. Серія «Філологія. Соціальні комунікації». 2018. Т. 29 (68) № 3. C. $55-60$.

7. Романченко А.П. Елітарна мовна особистість в епістолярному та щоденниковому дискурcax: аспекти дослідження. Проблеми загального і слов 'янського мовознавства. 2018. № 1. C. $111-120$.

8. Селіванова О.О. Сучасна лінгвістика: напрями та проблеми : підручник. Полтава : Довкілля-К, 2008. 712 с.

9. Boris Johnson's Twitter. URL: https:// twitter.com/borisjohnson.

10. Eger Maureen, Hjerm Mikael. What is tolerance and how much of it do democracies require? Open Democracy. 2019. URL: https:// www.opendemocracy.net/en/countering-radical-right/what-tolerance-and-how-much-it-dodemocracies-require/.

11. Fabricius Anne H. RP as sociolinguistic object. Nordic Journal of English Studies, 2002. Vol. 1. № 2. P. 355-372.

12. Mesthrie Rajend. The Cambridge Handbook of Sociolinguistics. Cambridge University Press, $2011.530 \mathrm{p}$.

13. Sunderland Jane. Gender, language and prejudice : Implicit sexism in the discourse of Boris Johnson. Open linguistics. 2020. № 6. P. 323-333.

\section{REFERENCES}

1. Vorkachev S. G. (2001) Lingvokul'turologija, jazykovaja lichnost', koncept: stanovlenie antropocentricheskoj paradigmy $\mathrm{v}$ jazyke znanij [Cultural linguistics, linguistic personality, concept: the formation of an anthropocentric paradigm in the language of knowledge]. Filologicheskie nauki, no 1, pp. 64-72 (in Russian).

2. Dubovickaja, M. A., Filatova N. P. (2019) Sociolingvisticheskij aspekt harakteristiki jazykovoj lichnosti [Sociolinguistic aspect characteristics of a linguistic personality]. Jazyk $i$ mir izuchaemogo jazyka: Sb. nauch. stat.
Saratov: Saratovskij social'no-jekonomicheskij institut (filial) federal'nogo gosudarstvennogo bjudzhetnogo obrazovatel'nogo uchrezhdenija vysshego obrazovanija "Rossijskij jekonomicheskij universitet im. G. V. Plehanova", pp. 26-31 (in Russian).

3. Zasyekina L. V. (2007) Movna osobystist v suchasnomu sotsialnomu prostori [Language Personality in Modern Social Space]. Ukrayinskyy tsentr politychnoho menedzhmentu, no 5 (25), pp. 82-89 (in Ukrainian).

4. Karaulov Ju. N. (2010) Russkij jazyk i jazykovaja lichnost' [Russian language and linguistic personality]. Moscow : Izdatel'stvo LKI, 264 p. (in Russian).

5. Ol'shanskij I. G. (2004) Jazyk i jazykovaja lichnost' v uslovijah sovremennogo social'nogo konteksta [Language and linguistic personality in the conditions of modern social context]. RGSU. Uchenye zapiski, no 1, pp. 79-80 (in Russian).

6. PavlovaL.V., TarasovaH.S.(2018)Komunikatyvni stratehii i taktyky v anhlomovnomu politychnomu mediadyskursi [Communication strategies and tactics in English-language political media discourse]. Vcheni zapysky TNU im. V. I. Vernadskoho. Seriia : Filolohiia. Sotsialni komunikatsii, vol 29 (68), no 3, pp. 55-60 (in Ukrainian).

7. Romanchenko A. P. (2018) Elitarna movna osobystist v epistoliarnomu ta shchodennykovomu dyskursakh: aspekty doslidzhennia [Elite linguistic personality in the epistolary and diary discourses: aspects of research]. Problemy zahalnoho i slovianskoho movoznavstva, no 1, pp. 111-120 (in Ukrainian).

8. Selivanova O. O. (2008) Suchasna linhvistyka: napriamy ta problemy: pidruchnyk [Modern linguistics: directions and problems: a textbook]. Poltava: Dovkillia-K, 712 p. (in Ukrainian).

9. Boris Johnson's Twitter. URL: https:// twitter.com/borisjohnson.

10. Eger Maureen, Hjerm Mikael. (2019) What is tolerance and how much of it do democracies require? Open Democracy. URL: https:// www.opendemocracy.net/en/countering-radicalright/what-tolerance-and-how-much-it-dodemocracies-require/.

11. Fabricius Anne H. (2002) RP as sociolinguistic object. Nordic Journal of English Studies, vol. 1, no 2, pp. 355-372.

12. Mesthrie Rajend. (2011) The Cambridge Handbook of Sociolinguistics. Cambridge University Press, $530 \mathrm{p}$.

13. Sunderland Jane. (2020) Gender, language and prejudice: Implicit sexism in the discourse of Boris Johnson. Open linguistics, no 6, pp. 323-333. 